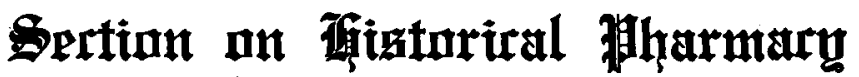

\author{
Papers Presented at the Sixtieth Annual Convention
}

\section{EARLY HISTORY OF PHARMACY IN KANSAS.}

L. E. SAYRE, LAWRENCE, KANSAS.

Any one who is familiar with Kansas history knows that its pioneer days were in about the year 1854. The next succeeding years were struggling times for the State.

In order to obtain historical data concerning Pharmacy of this early period, it has been necessary to search the records of the Historical Society at the capital city, Topeka. In these records I find in one of the early Kansas papers an account of a physician, pharmacist, and postmaster*-Dr. Geo. A. Cutler, who was one of the noted characters. After the adjournment of the free state convention at Lawrence, Dr. Cutler was taken sick with typhoid fever and lay ill at Governor Robinson's house for some time. When he became able to travel, by aid of assistance, he arrived at Doniphan, where he was pursued by ruffians; they found him and immediately hoisted him into a wagon and started for Atchison; upon arrival there, a courier was dispatched giving information that they had captured one of the leaders of the Abolition party. He was tried for high treason before the Squire and convicted, and given his choice to hang or be taken to LeCompton, where a pro-slavery army was gathering, preparatory to being taken to Lawrence. The sick man chose hanging. After much argument and dissension it was finally decided to take him to LeCompton, where he was placed in a tent. Shortly after this he was released and fell into the hands of a good nurse at Lawrence, who brought him back, as it were, "from the grave." Dr. Cutler in this history is noted as one who took part in the daily events of the period, so full of excitement and danger as that of the early history of Kansas. He helped recruit and organize the "Ragged Regiment," which General Lane, Colonel Dickey and Judge Morris Hunt patrolled through Idaho and entered Kansas about the first of August, 1856, and by forced march arrived in Topeka in time to hear the pro-slavery patriots on the Wakarusa near Lawrence, and started at once for the seat of war, and consequently was in the various fights that followed in quick succession.

In an early paper known as the "Commonwealth," we find a medical paper, one of the earliest contributions, written by Dr. Williamson, and read before the Medical Society. In it he tells how he used to practice medicine "when men's lives were not worth much," and gives incidents encountered during the troublesome times of ' 61 . He tells how a free state man, Dr. Eagles, was noti-

*Physicians, in the early days in Kansas, were mostly Dispensing Doctors (physicians and pharmacists combined.) 
fied by border ruffians to leave the territory or suffer consequences, which meant in those days the taking of his life and the pressing or stealing of his property for the simple reason that he was not, it is stated, "all right on the goose." In the summer of 1856, it is stated the Doctor "could beat a partridge hiding in the hazelbush and save his neck." He persisted in staying, and was a very good representative of the early "eclectic." In those days, it is stated that every other man who came (in 1856) had dubbed himself "professor" or "doctor," but the personal danger attending the practice of medicine soon thinned the ranks, so that the overworked doctors who accepted the situation had no light task. The writer gives us a number of cases of hairbreadth escapes during his hazardous attempts to practice medicine. The physician, it is stated, carried his life in his hands, and when he left home in the morning his death at night would not have been a surprise.

In Gray's Doniphan County History there appears as a frontispiece the figure of a savage, in his native costume, as the original owner of Doniphan County Kansas lands; the name of this savage is not mentioned. On page 86 the following statement is made: "The proprietors of Ayer's Ague Cure at one time owned land here. In the early days before the swamps and bogs had dried up, Dr. Ayer sold enough Ague Cure to purchase many good Doniphan county farms. There is not an old settler who will not tell you that the ague was more to be dreaded than the visits of the Indians. In territorial days business centers showed their enterprise in newspaper advertising in such historic papers as the "Kansas Press," "Kansas Freeman," "Kansas Weekly Herald," "The Herald of Freedom," the "Squatter Sovereign," etc. From the columns of these publications, and others, is transcribed the following:

The "Kansas Freeman," Oct. 25th, 1855-"Medicines, wholesale and retail, just received at Commercial Headquarters : 200 doz. boxes Grafenberg vegetable pills, 30 packages health bitters, $75 \mathrm{doz}$. boxes Green Mountain ointment, $60 \mathrm{doz}$. boxes fever and ague pills, 36 doz. children's panacea, 49 doz. sarsparilla, $20 \mathrm{doz}$. pile ointment, 40 doz. uterine catholicon, 5 doz. consumptive balm, $100 \mathrm{doz}$. cough candy. Another large bill has been shipped from New York so that the millions may be furnished here."

In the "Kansas Press," May 30, 1859, a full column advertisement is occupied by the following gentlemen, for drugs and medicines: S. F. Johnson, wholesale druggist, Cor. Delaware \& Main Streets, Leavenworth, at "St. Louis prices"; the Drug Market, E. E. Allen, wholesale and retail; advertisements of drugs including window glass, old whiskeys, Virginia tobacco, and stationery; Dr. G. J. Park, wholesaler and retailer of drugs, medicines, chemicals, paints, painters' materials, oils, burning fluids, varnishes and physicians' prescriptions, as well as family medicines; drugs by G. A. Eddy \& Co, wholesale and retail dealers, Delaware St., between 3rd and 4th, Leavenworth City, K. T.

In the Kansas Weekly Herald, dated Oct. 13, 1854, there appeared three columns of patent medicine advertisements : Dr. Easterly's Vermifuge, $1 / 8$ column; Dr. Hunter's German Bitters, I/8 column; Dr. Cook's Magic Hair Oil, I/s column; Dr. Easterly's Extract of Iodine and Sarsaparilla, 1 column ; Dr. Easterly's Fever and Ague Killer, $1 / 4$ column ; Dr. Carter's Cough Balsam, 3/4 column; Dr. Easterly's Pain Killer and Dr. Easterly's American Oil Liniment, $1 / 2$ column; 
also Dr. Baker's Specific, $1 / 8$ column, a remedy for venereal diseases, in which the doctor states: "This invaluable remedy has saved thousands upon thousands from the hands of merciless quacks, if not from a premature grave, etc."

The "Herald of Freedom," devoted to humanity and the interests of Kansas, of July 21, 1855, contains an advertisement by L. C. Talls, M. D., in which Dr. Talls states he has purchased the medicines, fixtures, etc., belonging to the late Dr. Clark, and says he is in readiness to answer all calls in line of his profession; dated Lawrence, June 2nd, 1855.

The "Squatter Sovereign," of Atchison, April 15, 1856, contains the following advertisement: "The University's family remedies should be under the sanction as well as the authority of the seal and authority of the University field of medicine and popular knowledge, chartered by the State of Pennsylvania, Apr. 29, 1853, with a capital of $\$ 100,000$, mainly for the purpose of arresting the evils of spurious and worthless nostrums, also for supplying the people with reliable remedies, whenever a competent physician cannot or will not be employed ; this institution located in Philadelphia, No. 68 Arch Street, where applications for new agencies will be received, has purchased from Dr. John Rowand his celebrated "Rowand's Tonic Mixture," known for upwards of twenty-five years as the only safe and sure cure for fever, ague, etc." The advertisement continues: "Remedies for fever and ague, bowel complaints, complaints of the lungs, dyspepsia, and constipation," and an almanac is issued by this company under the authority of F. S. Robertson \& Co., Miami, Saline County, Mo.

On page 56 of the "Early History of Leavenworth City and County Drug Stores:" The first drug store in the city was built and owned by Dr. Samuel Norton. who came from Weston, Mo., and who was one of the origina! Town Company. It was first a frame building and stood on the south side of Delaware street. just east of the corner of Second and Delaware streets, and was built late in the fall of 1854 . It was afterwards removed and the two-story brick building, known as the Norton building, was erected on the same site, and is still standing. Dr. R. E. Allen, late of Liberty, Mo., built and occupied as a drug store, about the same time, a one-story frame building on the west side of Main street, north of Delaware street, opposite the Anthony buildings.

In the "Cutler's History of Kansas, 1883, occurs on page 434, among the descriptions of the manufacturing industries of the city of Leavenworth, a description of the Brown Medicine and Manufacturing Co., pharmaceutical manufacturers and perfumers, No. 113 Delaware street. This house, it is stated, is largely engaged in the manufacture of pharmacopoeial and other pharmaceutical preparations. The company was organized in 1876 and has the following officers, most of whom have been from the beginning: G. A. Eddy, president; W. B. Slosson, vice-president; J. P. Baulserman, secretary; R. J. Brown, superintendent and treasurer. The latter gentleman was very active in the American Pharmaceutical Association. The annual sales of this firm, it is stated amounted to about \$75,000. Mr. William Spencer, graduate of the Philadelphia College of Pharmacy, associated with the establishment in 1884.

At the Capitol building Historical Museum there is exhibited in a show case a hand bill, reading as follows: "Prof. Miss Kate Bender can heal all sorts of 
diseases, can cure blindness, fits, deafness and all such diseases, also deaf and dumbness.

Residence, 14 miles east of Independence, on the road from Independence to Osage Mission, one and one-half miles S. E. of Norehead Station.

June 18, 1872.

Katie Bender."

This dodger was circulated by the notorious murderess, Kate Bender, herself. The Benders kept a road house, or feeding-place, on the main road leading from Osage Mission to the United States land office at Independence, Kansas. It is stated that the traveler lured by this advertisement, was sure to meet his death.

In the "History of Kansas," above referred to, there is a description of the Leis Chemical Co., mention of it being thus made: "This gigantic manufacturing establishment has grown to its present proportions mainly through the efforts of George Leis, who, as a druggist, commenced the manufacture of chemical preparations; for several years he continued their manufacture; on February 4, 1880, a stock company of the prominent business men of Lawrence was organized, with a capital of $\$ 50,000$; its first officers were J. P. Usher, president; I. N. Van Hoesen, vice-president ; George Leis, secretary and manager; H. Benson, treasurer; W. J. Leis, manufacturing and assistant manager. Patent medicines: The manufacture of patent medicines was commenced in a small way by Dr. S. O. Hymoe in 1867; according to the demand the business increased until the sales amounted to $\$ 150,000$ annually. His medicines embraced ten different varieties of chemical preparations for the manufacture of which its establishment employs eight experienced hands. Hymoe's remedies through the West, it is stated, are known for their purity and efficacy. Directors: H. C. Smith, W. G. Hills, C. E. Wilmoth, and J. D. Bowersock. In the autumn of 1882 a brick laboratory four stories high, $50 \times 85$ feet was completed at the cost of $\$ 18,000$, employing 55 skilled operatives-the Leis Manufacturing Co., manufacturers of Leis's standard medicines and pharmaceutical preparations, perfumery, fluid extracts, baking powder, etc.; 300,000 gross different preparations are manufactured annually. It is stated that the establishment is one of the most successful business enterprises in the state.

There is a record in 1860 that Drs. Gillihan and Packard in Iola, Kansas, emptied their medicine cases together and the result was the first drug store in that place. This passed to Gillihan \& Cowan, then to J. M. Cowan \& Son, then to S. Ridenour \& Co., then to John Francis, then to John M. Scott, then to Campbell \& Burrell.

The autobiography of Peter D. Ridenour, published in 1908, on page 269 states: "In the year $1866 \mathrm{my}$ brother Samuel came out from Ohio and proposed to select a location in Southern Kansas and go into the grocery and drug business, if $\mathrm{Mr}$. Baker and myself would take a half interest with him. He had been in the drug business in Ohio. The town of Iola in Allen County was selected; a small grocery store building was bought and stocked with drugs and groceries; he did the purchasing of drugs, and I bought the groceries. The firm of Ridenour-Baker Grocery Company is now one of the largest wholesale grocery stores in the middle west, located in Kansas City, Missouri."

In the Atchison Daily Free Press, May 8, 1855, I find two large advertising 
cards: drugs and sundries, M. W. Horn \& Co., and Buddington \& Co., the latter purporting to deal, in a wholesale and retail way, in foreign and domestic drugs.

One of the earliest advertisements of the Topeka drug stores we find in the Kansas Tribune, dated Aug. 15, 1857, in which C. C. \& E. P. Kellum, corner of Fifth and Kansas avenue, announce they are opening a general assortment of drugs and medicines, flavoring extracts, fancy articles; also books and stationery.

In the Leavenworth Times of April 25, 1886, there appears a cut of the large establishment of Geo. A. Eddy, wholesale druggist. Mr. Eddy commenced the drug business in Leavenworth in 1857; he employed two traveling salesmen for state work.

In the Leavenworth Directory, published in 1859-60, in the index of advertisements, the following firms appear: E. H. Anderson, G. A. Eddy \& Co., Samuel Norton, J. G. Park-each of these being given a portion of a page for advertising space.

In the History of Doniphan County, published in 1868, appears the notice of August Miller, Wathena, Kan.; A. Brantana, Troy, Kan.; and H. M. Sales \& Co., Doniphan, Kan.

The Kansas Herald, published at Leavenworth, June 15, 1855, contained an advertisement to the effect that Dr. Day has just received and is now opening a choice and select stock of pure drugs and chemicals, patent medicines, paints, oils.

The first medical publication in the state was published in Leavenworth as "The Leavenworth Medical Herald," by C. M. Logan, M. D., and T. Sinks, M. D., editors. Articles in this Medical Herald show that materia medica takes quite a prominent place as compared with surgery and practice. Theo. Eordorff, 409 Delaware St., Leavenworth, is stated as having one of the best known establish' ments in that city, and having an extensive drug house. Mr. Eordorff was originally from New York; began business in 1862, occupying a store 25x100 feet, three floors, and basement, and carrying from $\$ 40,000$ to $\$ 50,000$ stock, his sales amounting to $\$ 150,000$ per annum. One of his leading specialties is "Corn-wartSkin," also Medicated Malt Gin and Wahoo Bitters."

In the Cottonwood Falls, Kan., "Banner," Apr. 17, 1869, appears the advertisement of Dr. G. W. Williams, druggist-low prices, Cor. Broadway \& Friend Streets, Cottonwood Falls, Kan., advertising space about one-third column.

Dr. C. E. Sapp, located in Cimarron, is advertised as being "genial in his ways, and affability," and the doctor is stated to be a "thoroughly reliable gentleman, and leads in his profession."

In the Portrait Biographical Album published in 1890, it is stated that in 1875 Mr. H. W. Spangler, who was Justice of the Peace and Notary Public of Perry, and was one of the most active members of the Methodist Episcopal Church, had accepted the principalship of the Perry schools, which position he held until 1877, when he associated himself in partnership with Dr. Surber, and they purchased the drug stock of A. F. Gratigny and operated the drug business together; after one year Mr. Spangler became sole proprietor. Mr. Spangler was subsequently secretary of the Kansas Pharmaceutical Association.

In the publication known as "The Torch," dated March 17, 1882, there is a review of the history of Cherryvale, and reference is made to the many advantages and inducements offered to persons seeking homes and investments there. The 
first article refers to Richart \& McDonald as possessing a roomy drug store, in which there is a glittering write-up of this firm, the author stating, after several columns, that he regrets the space will not permit the privilege of describing their new store as it deserves, and their perfect system of running their business; the establishment, it is said, "stands alone, and is as strong as the rock of Gibraltar."

In the "Jacksonian," special edition, Cimarron, Kan., Jan. 1, 1887, there appears the following: "A. E. Krum's Star Drug Store," speaking of this as being in its holiday attire; The Diamond Drug Store, R. S. Pinnegar \& Co., referring to it as being a "shining sparkler of attraction and beauty"; Dr. J. W. Wade advertises as being a graduate of the Missouri Medical College of St. Louis, and the Medical Hospital of St. Joe, and the doctor is said to run a "city drug store."

In the Lawrence Gazette, July 21, is an account of the old business of B. W. Woodard, and refers to the business as a "relic of 1855 "; a reprint of the business card is given, and the memories that cluster around it are as follows: It is stated that this no doubt is the oldest Kansas business card extant, representing the oldest business house in the state. It is a fair specimen of the typographical art, printed in 1855, and reads as follows: "B. W. Woodard, dealer in drugs, medicines, paints, oils, dyes, window glass ware, perfumery, etc., books, stationery, etc. Physicians, farmers, and dealers are invited to call and examine the stock and prices, which will compare favorably with those of St. Louis houses." This advertisement appeared when Lawrence was but a frontier hamlet, mainly composed of sod and shack houses, and states that the building "with open glass front, was considered a wonder of substantiality and its interior finish a triumph of ascetic taste."

Mr. Frank Faxon, the well known member of the present firm of Faxon \& Gallagher, in response to the writer's request, has given an interesting account of his connection with the pioneer drug store as follows:

"I entered the employ of Mr. B. W. Woodard at Lawrence in the spring of 1863. At that time he had for his chief clerk Mr. George Leis, who was a studious fellow, and had made himself quite familiar with the U. S. Dispensatory and Parrish's Pharmacy. But he had never enjoyed the advantages of attending a pharmacy school. In August he left the employ of Mr. Woodard to accept a position as suttler's clerk in the army, which left me after little more than six months' experience head clerk and prescriptionist. I was between fifteen and sixteen years old and to me now it is a great wonder that Mr. Woodard could take such chances. I not only was trusted with the prescriptions in the day time, but slept in the store at night and was subject to calls at all hours. I think there must have been a special providence that watched over the doings of the drug clerks in those days. I suppose that I made some mistakes that I never knew of, and I know I made a few that came to my notice.

Filling a prescription one day, in which among other things, Aqua Font, was prescribed, the " $n$ " in Font. looked like an " $r$," and I remember the satisfaction I felt when I saw at a glance that Aqua. Fort. was called for. It showed that I had already learned something. I prepared the prescription and used nitric acid instead of fountain water, but as you will readily guess, the contents of the bottle soon escaped and reached the ceiling without delay. While engaged in this early 
prescription work I was of course closely watched by not only Mr. Woodard, but by the doctors whose prescriptions I was called upon to fill. I doubt if, at this time, there was a single graduate of pharmacy engaged in the drug business of the state of Kansas.

Two years after this time I was traveling in southern Kansas and was in a drug store when a customer called for one ounce of Tincture of Aconite Root. Upon his receiving it from the druggist he asked what the dose was, and after a slight hesitation the druggist replied, "O, about a teaspoonful." I interposed, the druggist took it all in good part, and it may be that a life was saved. At another time I entered another drug store conducted by a doctor. It was a very warm sultry day, and he was grinding something in a welgewood mortar. He was smoking a pipe and perspiring freely. He said to me "I am having a lot of trouble today making these Dover's Powders," and no wonder, for with the Opium and Ipecac he was trying to incorporate Salt Peter Commercial, which is probably $75 \%$ Rock Salt, and on warm days a very moist article.

I think it was about 1857 that Mr. Woodward started a drug store in the Eldridge house at Lawrence and brought from New York City a man by the name of Rixer, who was a pharmacy graduate, and who displayed his diploma on the front of a very handsome prescription case in the new store. It was the first certificate of the kind that I had ever seen, and I doubt if there were a half dozen in the state of Kansas at the time.

There are many other druggists who helped to shape the career of pharmacy in the state, whose descendants have been written to for information, but unfortunately we have been unable to secure from them any replies. Perhaps at some future time more extensive and interesting data to this history may be secured.

\section{DISCUSSION.}

Prof. Sayre remarked in connection with his paper just read that the records seemed to show that Doctor Ayres was one of the first men who introduced his ague-cure into Kansas, and it was said that he had sold enough of it to buy a large area of land in the state, which he believed was still owned by his family. He said that in this history he noted what he had always said, that the doctors were responsible for a large part of the patent-medicines that were sold. The doctors that located there did not hesitate to put up patent-medicines and sell them, and in the papers of that far-away period the doctors sold under their own names various articles of this kind, and it was related of one doctor that he had emptied his medicine-chest and started a drugstore, putting up his medicines and selling them as a druggist would. Most of the doctors in those days dispensed their own remedies, and little more than that, and promulgated the idea of putting up medicines that continued to this day. In Lawrence, for example, it had not been so many years since a doctor, who had now passed away, had two or three patent medicines that he put up and sold all over the state. The doctors should not say that the druggists were the only parties responsible for the introduction of patent medicines. He really thought the physicians themselves were mostly to blame for the creation of the business.

Mr. F. W. Meissner, of Indiana, said he had not had the long experience that Prof. Sayre had had, but he could remember back a great many years, when there were very few proprietaries which were not put up by the doctors, and which did not bear the title of "Doctor So-and-So's Remedy." The doctors were largely responsible for the general sale of proprietary medicines. It had only been in the last decade or two that druggists had been putting up proprietary remedies to any extent. 